（130） 直接基礎の地震時の滑動振動特性

建设省土木研究所 正員 大塚 久哲 建設省土木研究所 正員 運上 茂樹

1.はじめに 本文は、大規模地震時における直接基礎の骬動に対する安定照查条件の検討を目的とし、 基礎〜地盤系の非線形地震応答解析法を提案するとともに基礎の滑動振動特性に着目して行われた模型実験 結果のシミュレーション解析を行い、解析手法の妥当性を検討した結果をまとめたものである。

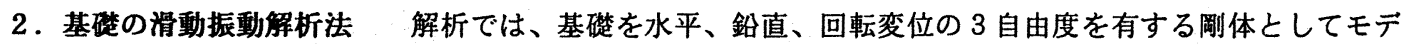
ル化し、これに上部構造や橋脚を 2 次元線形骨組構造モデルとして考虑することが可能な剛体基礎の滑動・ 転倒解析手法を用いた ${ }^{12)}$ 。風体基礎は、図一1に示すように、底面及び側面において、それぞれ、法線方 向の抵抗ばね及びこれに直交する方向のせん断ばねによりモデル化された地盤によって支持される。この基 礎〜地盤系に地震動加速度が作用する場合の運動方程式は次式のように表すことができる。ここで、系は $\mathrm{n}$ 個の節点を有するものとし、 $\mathrm{n}$ 番目の節点は剛体基䃈の重心を表わす。

$$
\begin{aligned}
& \mathrm{mx}_{\mathrm{x}} \ddot{X}+\mathrm{Fx}^{\mathrm{D}}+\mathrm{Fx}^{\mathrm{M}}=\left\{0,0, \cdots, 0, \mathrm{Fx}^{\mathrm{B}}+\mathrm{Fx}^{\mathrm{s}}\right\}^{\mathrm{T}} \\
& \mathrm{DY}_{\mathrm{Y}} \ddot{\mathrm{F}}_{\mathrm{Y}}{ }^{\mathrm{D}}+\mathrm{F}_{\mathrm{Y}}{ }^{\mathrm{M}}=\left\{0,0, \cdots, 0, \mathrm{Fy}_{\mathrm{B}}^{\mathrm{B}}+\mathrm{F}_{\mathrm{Y}}{ }^{\mathrm{S}}-\mathrm{F}_{\mathrm{Y}}{ }^{\mathrm{G}}\right\}^{\mathrm{T}} \\
& \ddot{\mathrm{j}} \ddot{\theta}+M^{\mathrm{D}}+M^{\mathrm{M}}=\left\{0,0, \cdots, 0, M_{\mathrm{x}}{ }^{\mathrm{B}}+\mathrm{Mx}^{\mathrm{s}}+\mathrm{My}^{\mathrm{B}}+M_{\mathrm{y}}{ }^{\mathrm{s}}\right\}^{\mathrm{T}}
\end{aligned}
$$

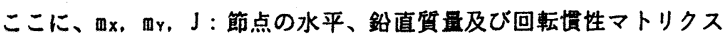

$$
\begin{aligned}
& X, Y, \theta \text { : 節点の絶対変位（水平、鉛直、回轱成分）ベクトル }
\end{aligned}
$$

底面及び側面において剛体基礎を支持する地盤ばねは離散化した 分布ばねにより表すものとする。基䃈底面では、地盤ばねによる復 元力と同時に回転振動に伴って生じる基䃈と地盤との衝突による速 度低下を考虑するために隇衰力を考虑する。法線方向の抵抗ばねに よる復元力は、図ー2に示すように圧縮力に対してはバイリニア型 のばねで抵抗し、引張力に対しては剥離するものとする。基礎側面 でも底面と同様にバイリニア型の復元力を考虑するものとするが、 衝突による減衰作用は生じないものとする。

基礎底面及び側面におけるせん断ばねは、図一 3 に示すように水 平力が、摩擦係数により定められる値に達した時に復元力が一定と なるバイリニア型のばねでモデル化する。なお、静摩擦力と動摩擦 力を考虑する。

回転振動に伴って生じる基礎底面と地盤との衝突による速度低下 を考慮するための減衰力は次のように定めた。基礎に浮き上がりが 生じて、底面と地盤とが衝突する時、衝突前後の速度を、それぞれ $\mathrm{v}$ 及び $\mathrm{v}^{\prime}$ とすれば反発係数Cは次式のように定義される。

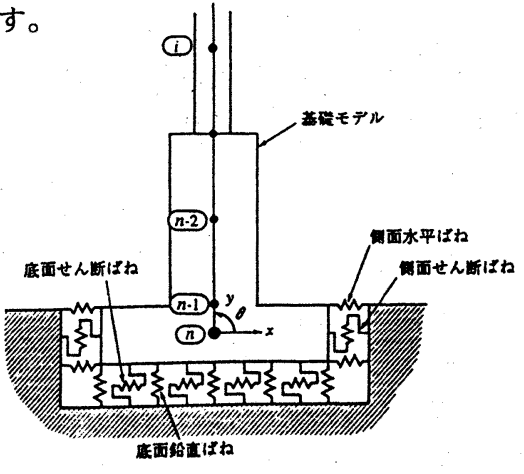

図-1 基礎の滑動振動解析モデル

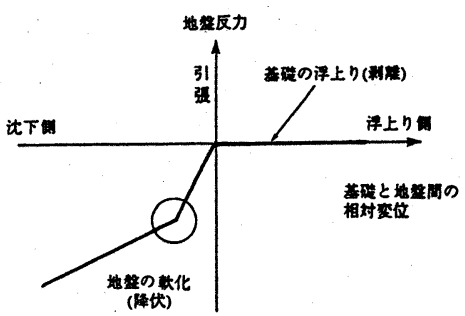

困-2 基䃈底面及び側面における法線方向地盤 ばねのモデル化

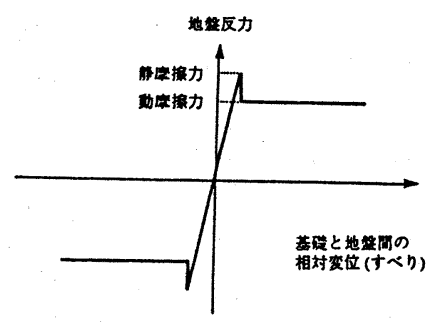

图-3基礎底面及び側面におけるせん断ばねの モデル化 


$$
\mathrm{C}=-\mathrm{v}^{\prime} / \mathrm{v}
$$

1 自由度振動系が衝突する場合の衝突前後の速度と 系の減衰定数の関係は次式のように表せる。

$$
2 \pi \mathrm{h} / \sqrt{ }\left(1-\mathrm{h}^{2}\right)=\ln \left(\mathrm{v}^{\prime} / \mathrm{v}\right)
$$

式(2)を式(3)に代入すると次式を得る。

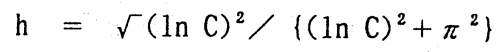

以上から衝突による速度低下を考虑するために地盤

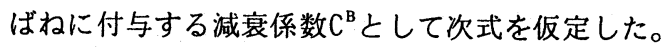

$$
\mathrm{C}^{\mathrm{B}}=2 \mathrm{~h} \sqrt{ }\left(\mathrm{m}_{\mathrm{Y}_{\mathrm{n}}} \cdot \mathrm{K}_{\mathrm{Y}}{ }^{\mathrm{B}}\right)
$$

$$
\text { ここに、 }
$$

$\mathrm{m}_{\mathrm{Y}} \mathrm{n}$ : 剛体基礎の質量の鉛直成分

$\mathrm{K}_{\mathrm{Y}}{ }^{\mathrm{B}}$ : 底面の法線方向の抵抗ばねの 1 次剛性

上部構造及び橋脚の隇衰力は、各振動モードごとに 任意の減衰定数を与えたり、ひずみエネルギー比例減 衰法によって部材別に減衰定数を与えることができる。 なお、本文の解析では、橋脚躯体や上部構造のない剛 体基礎模型を対象としたものであるため、基䃈底面に おいてばねで支持された剛体基礎のみをモデル化して いる。

\section{3. 基碟模型の滑動振動実験}

解析対象は、コンクリートモルタル製の基礎模型を 用いた振動台実験 ${ }^{3)}$-5) とした。以下に実験の概要を示 す。図ー4 は、実験の概要図を示したものである。摩 擦係数を調整するためのテフロン板（厚さ $1 \mathrm{~cm}$ ）または塩化ビニル板（厚さ $1 \mathrm{~cm}$ ）を取り付けた厚さ $3 \mathrm{~cm} の$ 耐水性合板を振動台上に固定し、この上にコンクリートモルタル製の基礎模型を載せた。テフロン板は合板 にビス止め、塩化ビニル板はエポキシ樹脂系の接着郕で固定した。基礎模型としては、幅及び高さが約 $30 \mathrm{~cm}$ 、 重量 $90 \mathrm{kgf}$ 程度の円柱体及び直方体の 2 種類とし、その諸元は表一 1 に示すとおりである。摩擦係数を調整す るため用いたテフロン板及び塩ビ板と基礎模型間の摩摖係数を水平方向の引張試験により測定したところ、 静止摩擦係数は、それぞれ、0.24程度及び0.49〜0.57程度となる。動摩擦係数は静止摩擦係数よりも約 $20 \%$ 程度小さい。反発係数については、直径 $10 \mathrm{~cm}$ 、厚さ約 $3 \mathrm{~cm}$ の円柱コンクリートブロックを高さ約 $30 \mathrm{~cm}$ から落 下させる実験を行い、衝突後のはね上がり最大高さから算出した。

加振実験では、正弦波及び地震波を入力した。正弦波入力では、加振振動数及び最大加速度振幅を変化さ せ、地震波入力では、地震波の種類、入力加速度の大きさを変化させ、基礎の応答加速度や滑動量について 検討した。入力地震動としては、地盤種別の相違を考虑し、それぞれ、1978年宮城県沖地震時の開北橋周辺 地盤上記録（I 種地盤）、1968年日向灘沖地震時の板島橋周辺地盤上記録（II 種地盤）、及び1983年日本海 中部地震時の津軽大橋周辺地盤上記録 (III種地盤) の 3 波を用いた。なお、必要な加速度値を得るために時 間軸は $1 / 2$ にしいる。実験では、振動台への入力加速度及び基礎模型の応答加速度を加速度計により計測し た。また、正弦波加振実験では、基礎模型をビデオカメラで撮影し、画像解析装置により変位を求めた。

\section{4. 振動実験結果のシミュレーション解析}

模型実験のシミュレーション解析として、模型形状 (订柱体、直方体) や摩擦係数（テフロン板、塩化ビ ニル板）、また入力加速度等を変化させた実験それぞれについて行ったが、結果はいずれも同様であった。 このため、ここでは円柱体模型をテフロン板上に設置した場合の解析例を示す。 
解析に用いた数值データは、表一 1 の通りである。ただし、解析では地盤を分布ばねでモデル化するため、 模型を支持するばね係数の值を適切に与えることが重要である。ここでは、鉛直方向のばね係数については テフロン板の弾性係数から求めた。ただし、このようにして求めたばね係数は $2.7 \times 10^{5}(\mathrm{kgf} / \mathrm{cm})$ と大きくな るため、数值解析上発散が生じる場合も生じた。このため、鉛直方向のばね係数としては $1 / 100 に$ 隇じた值を 用いた。ばね係数を小さくすると変位が大きく計算されることになるが、ばね係数が上記の範囲では大きく 影響しない。模型底面に設置した分布ばねは10個とした。分布ばねの分割数については、基礎底面に剥離を 伴うロッキング振動が生じる場合でも10程度以上に分割すれば分割数の影響を大きく受けないことを確認し ている。なお、数值積分時間間隔は $1 / 1,000$ 秒とした。

\section{（1）正弦波加振実験}

図ー 5 は、制御加速度振幅 $400 \mathrm{gal}$ 、加振振動数 $3 \mathrm{~Hz}$ の正弦波を入力した場合の模型の加速度及び変位の応 答波形を示したものである。実験では、模型にすべりが生じると応答加速度は摩擦係数に相当する加速度で 平坦化され、これ以上の加速度応答は生じない。解析でも同様にすべりによる応答加速度の平坦化がシミュ レーションできる。ただし、振動台に対する相対変位を見てみると、実験では一方向に滑りが蓄積し最終的 には約 $5 \mathrm{~cm}$ 残留変位が生じているが、解析では同じ方向に残留変位は生じているが、その大きさは約 $1 \mathrm{~cm}$ と実験值の $1 / 5$ 程度である。剛体が正弦波振動を受けて滑動する理想的な状態では、剛体は初期の位置を中心 にすべりが生じ、残留変位は一方向に蓄積しない。しかしながら、実験では振動台またはテフロン板のわず かな傾斜、振動台への加振加速度の非対称性、テフロン板の摩擦係数の平面的なばらつきなどが残留変位に 大きく影響していると考えられる。振動台の加振加速度の非対称性の影響は解析に考虑できるが、その他を 解析に見込むことは困難である。一方、模型の滑動振動中の滑動振幅に着目すると、実験では $2 \mathrm{~cm} 、$ 解析で は2. $2 \mathrm{~cm}$ となりよい精度で追跡できることがわかる。

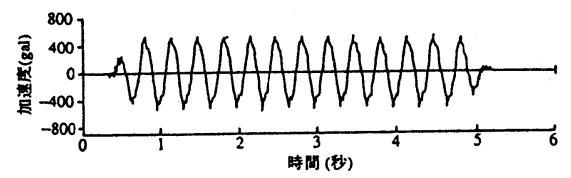

(1) 入力加速度

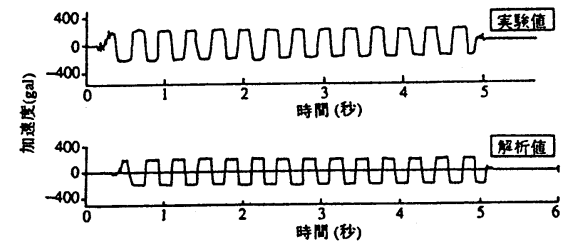

(2) 応答加速度

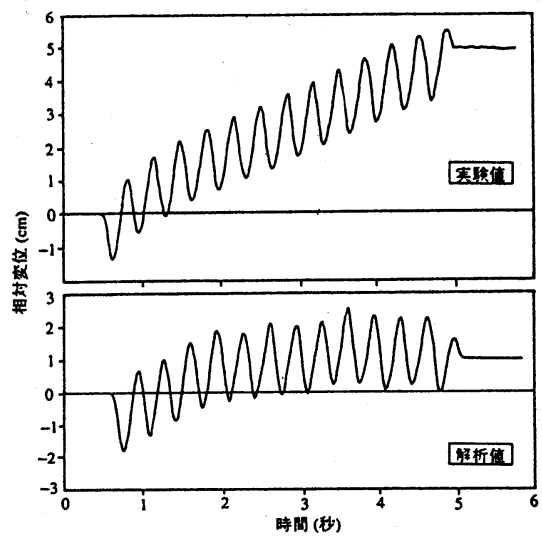

(3) 応答怒位

図ー 5 正弦波加振実呀のシミュレーション解析（制御加速度振幅400gal、加振振動数 $3 \mathrm{~Hz}$ ）

\section{（2）地震波加振実験}

図-6 は、開北橋記録の水平成分の最大加速度を $500 \mathrm{gal}$ に調整して入力した場合の応答加速度及び応答変 位の時刻歴波形について実験值と解析値を比較して示したものである。また、表 -2 は、開北橋記録と併せ て板島橋記録、津軽大橋記録に対する実験結果と解析結果の最大応答値を比較したものである。

開北橋記録を入力した場合には、大きなすべり変位が、時刻約 4 秒と 6 秒に 2 回生じており、これは解析 結果にも同様に表れている。残留変位は、実験では $0.48 \mathrm{~cm}$ 、解析では $0.34 \mathrm{~cm}$ である。実験時の摩擦係数等の ばらつきを考虑すれば解析でよく追跡できているといえる。板島橋記録の残留変位は、実験では $0.53 \mathrm{~cm} 、$ 解

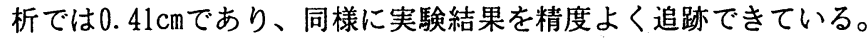

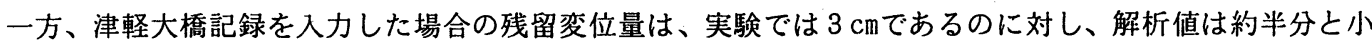



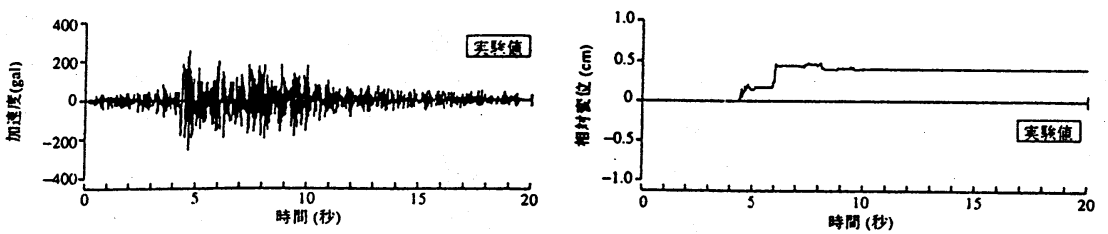

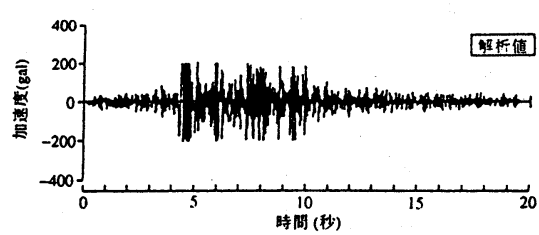

(1) 応答加速度

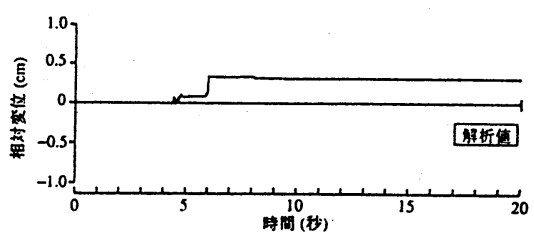

(2) 相対変位

図一－6 地震波加振実験のシミュレーション解析（開北棉記録、最大加速度500gal）

表一 2 地震波加振実鈎結果と解析結果の最大応答値の比較

\begin{tabular}{|c|c|c|c|c|c|c|c|}
\hline \multirow[t]{2}{*}{ 加速度波形 } & \multirow{2}{*}{$\begin{array}{c}\text { 振動台の } \\
\text { 最大加速度 } \\
\left(\mathrm{cm} / \mathrm{s}^{2}\right)\end{array}$} & \multicolumn{2}{|c|}{$\begin{array}{c}\text { 模型の最大加速度 } \\
\left(\mathrm{cm} / \mathrm{s}^{2}\right)\end{array}$} & \multicolumn{2}{|c|}{$\begin{array}{c}\text { 模型の最大相対変位 } \\
(\mathrm{cm})\end{array}$} & \multicolumn{2}{|c|}{$\begin{array}{c}\text { 加振後の残留资位 } \\
(\mathrm{cm})\end{array}$} \\
\hline & & 実験値 & 解析値 & 実験值 & 解析值 & 実呀値 & 解析值 \\
\hline 開北橋記録 & 521 & 257 & 203 & 0.48 & 0.34 & 0.40 & 0.31 \\
\hline 板島橋記録 & 513 & 240 & 203 & -0.53 & -0.41 & -0.50 & -0.40 \\
\hline 津軽大橋記録 & 513 & 207 & 204 & 3.01 & 1.35 & 2.90 & 1.19 \\
\hline
\end{tabular}

さい。これは、津軽大橋記録を入力した場合にはすべりが生じる加速度を超える回数が多くなり、すべりが 何度も生じるため、1 回 1 回のすべりの差異が累積され、最終的な残留変位と実験值とがよく一致しないた めと考えられる。しかしながら、前述のように振動台のわずかな傾斜や摩擦係数の平面的なばらつきなども 考虑すると解析結果は実験値をかなりよく再現できているということができよう。

\section{5. 結詥}

以上の検討結果をまとめると次の通りである。

1 ) テフロン板上の円柱体模型の正弦波加振の場合について、模型にすべりが生じると応答加速度は摩擦係 数に相当する加速度で平坦化され、それ以上の応答加速度が生じないという実駼結果を解析で表わすことが できた。

2 ) 正弦波加振終了後の残留変位については、解析值と実験値はよく一致しなかった。ただし、これは振動 台や合板のわずかな傾斜、テフロン板の摩擦係数の平面的なばらつきなどが残留変位に影響するために生じ る䛊差と考えられる。模型の滑動振幅については、解析結果は実験結果をよい精度で推定することができる。 3) 開北橋記録（I 種地盤）と板島橋記録（II 種地盤）を入力した地震波加振では大きなすべり変位が数回 だけ生じ、解析でもこれをよく表すことができる。、正種地盤上の津軽大橋記録を入力した地震波加振では、 すべりの回数が多い。すべりが生じる時刻は解析結果と実験結果はよく一致しているが、1 回 1 回のすべり 量の差異が累積されるため、最終的な残留変位の解析値は実験値の約半分と小さい。

\section{参考文觔}

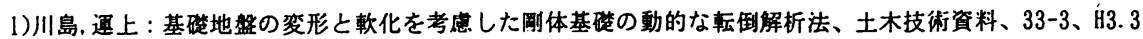

2)川島，運上，向：地震時の直接基碳の回転振動特性、土木技術盗料、36-7、H6.7

3)大塚，細川：地展時におけろケーリ基喽の滑動现象に着目した振動台模型実稌、土研資料、3300号、H. 6.8

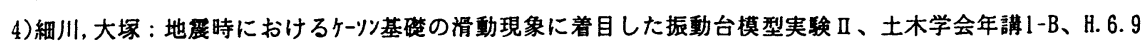

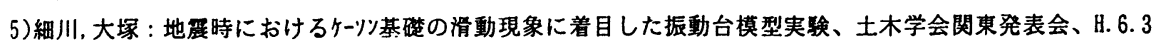

6)大塚，遇上，向：基碳の滑動振動のシミュレーション解析、土木技術資料、37-3、H. 7.3 